\title{
A GIS-Based Multi-Criteria Evaluation of Landfill Site Selection in Lahore, Pakistan
}

\author{
Khadija Asif', Muhammad Nawaz Chaudhry ${ }^{1 *}$, Uzma Ashraf ${ }^{1}$, \\ Imran Ali ${ }^{2}$, Mustafa Ali ${ }^{3}$ \\ ${ }^{1}$ Department of Environmental Sciences and Policy, Lahore School of Economics, Lahore, Punjab, Pakistan \\ ${ }^{2}$ Center for Geographic Information Systems, University of Punjab, Lahore, Punjab, Pakistan \\ ${ }^{3}$ School of Environmental Science and Engineering, Shanghai Jiao Tong University, Shanghai Shi, China
}

Received: 5 June 2018

Accepted: 16 September 2018

\begin{abstract}
In Pakistan, solid waste management (SWM) is considered to be a serious problem, with most of the hazardousand non-hazardous waste being dumped in landfills without any segregation. The key objective of our research was to select a suitable landfill site that is environmentally sound, economically feasible and socially acceptable for metropolitan Lahore. Lahore District is located in one of the world's largest fluvial plains, namely the Indo-Gangetic meandering rivers system plain. There is only one functional landfill site situated in the northern part of the city. Multi-criteria decision aid (MCDA) and geographical information system were combined and used in this research that blends two aggregation methods: weight linear combination (WCL) and assigning criteria weights. The analytical hierarchy process (AHP) pair-wise comparison method was applied for assigning weights to the 9 delineated criteria. The result of the analysis show that $7(6.26 \%$ highly suitable) possible sites are available that are greater than 50 ha in area. The selected potential landfill locations were contrasted with each other in connection to their land size, distance from nearby settlements and from the city center. The result shows that site number 6, with a weight of $0.22(22.21 \%)$, is the most suitable location for a landfill site in Lahore. In addition, landfill site 4 is considered the least preferable site due to its weight. This site has the least environmental and social impacts, as it is at a reasonable distance from settlements and is at the same time comparatively closer to the city center. This study highlights the importance of the landfill siting process for the fluvial plain and helps in decision making.
\end{abstract}

Keywords: Analytical hierarchy process (AHP), landfill site, Multi-criteria decision aid, metropolitan city, municipal solid waste

*e-mail: muhammadnawazchaudhry@yahoo.com 


\section{Introduction}

Municipal solid waste generation is a critical environmental and public health concern in different countries of the world. It is especially serious in developing countries that lack the necessary infrastructure for proper waste collection and disposal activities [1-2]. In such countries, most of the waste is usually either thrown in open dumps or deposited in non-sanitary landfill sites. This in turn may result in generating toxic leachates and significant greenhouse gas emissions that contribute to global warming and environmental degradation [3-4]. Moreover, recent studies in such countries have established a direct link between poor waste management practices and infectious diseases among scavengers and waste collectors [2]. Apart from a lack of proper financial resources, waste management in these countries is also plagued by poor planning and implementation of environmental rules and procedures [5]. Rapid urbanization rates in some of these countries might amplify the magnitude of this problem in the future [2]. Landfilling is the final disposal stage of waste residuals all over the world [6]. However, in developing countries a large number of communities are still practicing landfilling and open dumping for total waste disposal without any preprocessing [7]. Landfill siting is a multifaceted, tedious and expensive process, as it requires the application of numerous standards from social, economic, political and environmental points of view [8-9].

Pakistan is a rapidly urbanizing country in South Asia and it is already the fifth most populous country in the world. Some of its cities can be counted among the most populous cities in the world [10]. Such cities include Lahore, which is the provincial capital in the political and economic heartland of the country. So far the city lacks proper waste management facilities, which makes hygienic disposal of its 6000 tons of daily waste a serious epidemiological and environmental concern [11]. Furthermore, one of the major dumping sites as well as the newly constructed landfill site is very close to the main surface water body: the River Ravi. The landfill site is constructed on the thick channel sands of an abandoned Ravi channel with poor geological and hydrological conditions and will eventually pollute the water through its leachate since the water table is either negative or only $1 \mathrm{~m}$ deep.

The objective of this study was to select a suitable landfill site that is environmentally sound, economically feasible and socially acceptable for the city of Lahore. We aimed to apply analytical hierarchy process (AHP) and multi criteria decision analysis (MCDA) techniques for evaluating and selecting a suitable landfill site for the city.

\section{Material and Methods}

\section{Study Area}

Lahore is the second largest city of Pakistan and the $26 \mathrm{t}^{\mathrm{h}}$ largest city in the world [12]. According to the census of 2017, the total population of Lahore is 11.13 million and covers a total land area of $1772.43 \mathrm{~km}^{2}$ [13].

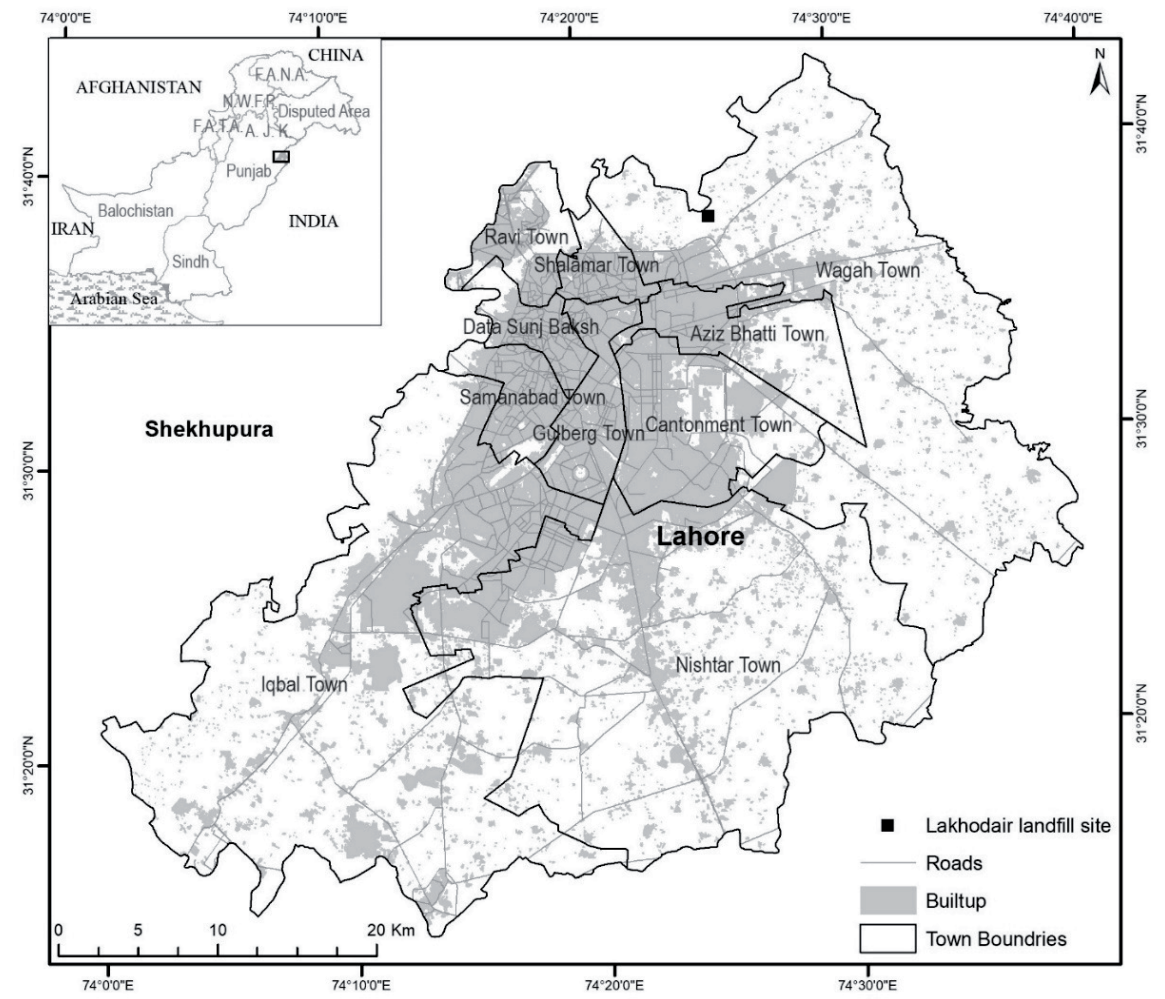

Fig. 1. Study area map. 
Around $82 \%$ of the total population lives in the urban area and the other $18 \%$ lives in rural zones surrounding the city [14], which is located in the northeastern part of the country and is the provincial capital of Pakistani Punjab, lying between $31^{\circ} 15^{\prime}$ to $31^{\circ} 45^{\prime}$ north and $74^{\circ} 0^{\prime}$ to $74^{\circ} 40^{\prime}$ east (Fig. 1). The growing population and changes in land use patterns have resulted in an increase of solid waste generation over the years. Currently, total municipal solid waste (MSW) production in Lahore is about 6000 tons per day [1]. The city has only one landfill site, which is inadequate for disposing of waste coming from the whole city.

\section{Data Preparation}

Various criteria were used for the selection of landfill sites in this study. The environmental, political, social and economic criteria were further divided into sub-criteria. We have used and evaluated nine different input map layers including geology/lithology, economic land value, airport, settlements (urban), groundwater (aquifers), surface water, existing dumping and landfill sites, railway line, and roads [15]. Prior to the suitability analysis the data were prepared in an Arc GIS environment. Arc GIS 10.5 software was used to prepare map layers of the study area. In order to make land-use images more precise, some of the land-use units were recorded by using references from high-resolution Google Earth Images [16]. A common coordinate reference system was used in preparing all layers. For the weightage analysis purpose all of the input layers were rasterized to $10 \mathrm{~m}$ grid size [17].

Vector data of road network, settlement and railway lines were obtained from LDA (Lahore Development Authority). Data for groundwater aquifer and surface water bodies were collected from WASA (Water and Sanitation Agency). Data of existing dumping sites and landfill sites were obtained from LWMC (Lahore Waste Management Company). The geological layer was prepared from a GSP (Geological Survey of Pakistan) map and was geometrically registered with the exact location of the study area.

\section{Processing}

We utilized a variety of GIS spatial analysis tools to accomplish the core objectives of this research, such as digitizing, buffering, overlay, MCDA (multi-criteria decision aid)/MCE (multi-criteria evaluation) and AHP (analytical hierarchy process) [18]. The stepwise methodology used in this study is explained in the following section.

\section{Multi-Criteria Decision Aid (MCDA)/Multi-Criteria Evaluation (MCE)}

Multi-criteria decision aid (MCDA) offers a set of strategies, procedures and calculations for organizing choice issues, planning, assessing and prioritizing choice alternatives [19-20]. Moreover, MCDA can possibly decrease the expenses and time by narrowing down the possibilities [21]. The availability of numerous scales helps in measuring the significance of each criteria over another [22]. In order to compare criteria with each other, all units were transformed into the same comparable unit of measurement scale [23]. Standardization was done by assigning a suitability ranking. These ranks were assigned to each of the criteria based on expert opinion. The prepared layers were evaluated in GIS [24].

\section{Assigning Criteria Weight (ACW)}

Assigning criterion weights (ACW) to each factor map is one of the major parts of the GIS-based multicriteria evaluation (MCE). Assigning weights in the landfill site selection process is to express the significance or preference of each variable with respect to others. The methodology incorporates "ranking, rating, pair-wise comparison, and trade-off analysis" [25].

Pairwise-comparison lessens the complication in decision-making, as two components are considered at a time. This process includes three stages:

i. The development of a comparison matrix at every level of the hierarchy.

ii. Computing the weights for each factor.

iii. Approximation of consistency ratio (CR).

In the decision-making process, one of the major pair-wise comparisons developed is known as the analytical hierarchical process (AHP). Using this method in MCE, it is important that the weights add up to 1 . AHP is computed for the 9 criteria selected for landfill site selection for this study, which are shown in Table 2. In AHP, weight can be determined by taking the essential eigenvector of a square reciprocal matrix of pair-wise comparisons between the criteria [26]. This approach reflects the significance of the two criteria required at the same time. The consistency ratio (CR) value is very important, as it reveals inconsistencies that may have emerged during pair-wise comparison. The desired CR value must be $<0.1$. If the value is greater than 0.1 , then some of the pair-wise comparison values must be reconsidered [24].

A scale with values from 1 to 9 was used for the pair-wise comparison matrix. In cases where the column and row factors are equally important, they have a rating value of 1 [24]. On the other hand, the rating $1 / 9$ demonstrates that the column factor is very important relative to the row factor, whereas rating 9 shows that the row factor is more important than the column factor [26]. Based on this AHP weight derivation module, the weights for all factors considered for landfill site selection were generated. The weight linear combination (WLC) technique was used to derive the weight average for each criterion. Based on these weight results an intermediate suitability map was prepared through GIS. 
Table 1. Criteria used in landfill site selection.

\begin{tabular}{|c|c|c|c|}
\hline Criteria & $\begin{array}{c}\text { Buffer distance } \\
\text { (m per Class) }\end{array}$ & Suitability & Ranking \\
\hline \multirow{4}{*}{$\begin{array}{c}\text { Distance } \\
\text { from surface } \\
\text { water }\end{array}$} & $0-300$ & Unsuitable & 1 \\
\hline & $300-700$ & Less Suitable & 3 \\
\hline & $700-1500$ & Suitable & 7 \\
\hline & $>1500$ & Highly Suitable & 9 \\
\hline \multirow{4}{*}{$\begin{array}{l}\text { Distance } \\
\text { from } \\
\text { settlements }\end{array}$} & $0-200$ & Unsuitable & 1 \\
\hline & $200-500$ & Less Suitable & 3 \\
\hline & $500-1000$ & Suitable & 7 \\
\hline & $>1000$ & Highly Suitable & 9 \\
\hline \multirow{4}{*}{$\begin{array}{l}\text { Distance } \\
\text { from road } \\
\text { network }\end{array}$} & $0-500$ & Unsuitable & 1 \\
\hline & $500-1000$ & Less Suitable & 3 \\
\hline & $1000-1500$ & Suitable & 7 \\
\hline & $>1500$ & Highly Suitable & 9 \\
\hline \multirow{4}{*}{$\begin{array}{c}\text { Distance } \\
\text { from Airport }\end{array}$} & $0-1000$ & Unsuitable & 1 \\
\hline & $1000-3000$ & Less Suitable & 3 \\
\hline & $3000-5000$ & Suitable & 7 \\
\hline & $>5000$ & Highly Suitable & 9 \\
\hline \multirow{4}{*}{$\begin{array}{l}\text { Distance } \\
\text { from } \\
\text { Railway } \\
\text { lines }\end{array}$} & $0-200$ & Unsuitable & 1 \\
\hline & $200-500$ & Less Suitable & 3 \\
\hline & $500-1000$ & Suitable & 7 \\
\hline & $>1000$ & Highly Suitable & 9 \\
\hline \multirow{4}{*}{$\begin{array}{l}\text { Distance } \\
\text { from } \\
\text { Existing } \\
\text { dumping } \\
\text { sites }\end{array}$} & $0-1000$ & Unsuitable & 1 \\
\hline & $1000-2500$ & Less Suitable & 3 \\
\hline & $2500-5000$ & Suitable & 7 \\
\hline & $>5000$ & Highly Suitable & 9 \\
\hline \multirow{3}{*}{ Geology } & $\begin{array}{c}\text { High } \\
\text { permeability }\end{array}$ & Unsuitable & 1 \\
\hline & $\begin{array}{c}\text { Medium } \\
\text { permeability }\end{array}$ & Less suitable & 3 \\
\hline & $\begin{array}{c}\text { Less } \\
\text { permeability }\end{array}$ & Suitable & 9 \\
\hline \multirow{3}{*}{$\begin{array}{l}\text { Economic } \\
\text { zoning }\end{array}$} & $\begin{array}{l}\text { High land } \\
\text { cost }\end{array}$ & Unsuitable & 1 \\
\hline & $\begin{array}{l}\text { Medium land } \\
\text { cost }\end{array}$ & Less Suitable & 3 \\
\hline & $\begin{array}{l}\text { Low land } \\
\text { cost }\end{array}$ & Suitable & 9 \\
\hline \multirow{4}{*}{$\begin{array}{l}\text { Depth of } \\
\text { Ground } \\
\text { water }\end{array}$} & 148 & Unsuitable & 1 \\
\hline & 175 & Less suitable & 3 \\
\hline & 212 & Suitable & 7 \\
\hline & 230 & Highly Suitable & 9 \\
\hline
\end{tabular}

The final suitable sites were chosen from a suitability map using the layer weights criteria. Moreover, all the candidate sites were further evaluated based on three criteria: size of landfill, distance from settlement and distance from the city center. Furthermore, an AHP was constructed to prioritize the selected candidate sites [27]. Table 1 shows the buffer distances of each criterion and standardized ranking based on threshold values.

\section{Results and Discussion}

\section{Evaluation Criteria}

\section{Geology}

Consolidated rocks with less permeability is the best combination for any landfill site. Highly fractured and weathered rocks are not suitable for any type of landfill siting because of their high permeability [28]. Moreover, it is essential to know the soil developed on the strata [29]. Geologically, the Lahore aquifer is part of the fluvial package that is a constituent part of one of the world's biggest fluvial plains - namely the Indo-Gangetic plain built by the Indus and Ganga rivers and their tributaries. This vast package was deposited by meandering river systems and is composed predominantly of sand with discontinuous horizons of silt, silty clay and clay [30].

The fluvial facies include channel belt sands, levees, back swamps, oxbow lakes, abandoned river channels and flood plain deposits. Any effort to build a sanitary landfill without understanding the fluvial geology and hydrology is counter-productive. This study strongly suggests a greater weight to the geology of the entire Indo-Gangetic Plain and other fluvial plains built by a meandering river system globally. However, in many areas of Lahore, thick silty and clay beds occur, which protect the aquifer from pollution and seepage. Chung formation aeolian deposits are predominantly silts with subordinate argillaceous and arenaceous sediments. The unit is separable into two sections. The upper part is silty clay, caramel to khaki dark in shading, thickly bedded with kankers and minor silt layers that measure 7-10 m. Landfill sites can also be locted here. The lower part involves red and dark sandy silt and fine sediment, having slim layers of fine sand/silt. These beds are harder, kankariferous and compressed [31].

\section{Distance from Surface Water Bodies}

The contaminated runoff from a landfill would have an adverse effect on surface water bodies. A landfill site ought not to be in the floodplain region $[8,15]$. A multiple ring buffering tool was used to prepare multiple polygons around water bodies within the following distances: 0-300, 300-700, 700-1500, $>1500 \mathrm{~m}$. In order to reduce water pollution, a 0-300 m buffer area was omitted for landfill siting. 


\section{Distance from Surface Built-up Area}

The landfill must be $1000 \mathrm{~m}$ from the residential areas, whereas it can be $500 \mathrm{~m}$ from industrial zones [8]. Built-up area of Lahore include diverse settlements, private and government properties, schools and hospitals, and commercial and industrial zones. The multiple ring buffer analysis tool was used to prepare multiple polygons around the built-up areas within the following distances: 0-200, 200-500, 500-1000, $>1000 \mathrm{~m}$. A buffer of 0-200 m was omitted.

\section{Distance from Road Vetwork}

This criterion should be considered from economic and social points of view, as siting a landfill very close to roads may result in public health problems. Moreover, landfill sites very far from road networks are not recommended due to the higher transportation cost [32-34]. In this study, a distance of 1000-1500 $\mathrm{m}$ and $1500 \mathrm{~m}$ is considered as moderately to highly suitable, respectively. Generally, the buffer area of 500-1000 $\mathrm{m}$ is considered as less suitable for landfill siting.

\section{Distance from Roads and Airport}

Different values are related to safe distances from airports, such as 3000 and $3500 \mathrm{~m}$ [35-37]. By considering these suggested values, the safe distance from the airport was determined as 3000-5000 m and $>5000 \mathrm{~m}$. In order to lessen the social and environmental impacts, $0-1000 \mathrm{~m}$ buffer areas were omitted for landfill siting. The proximity of landfill sites to any airport can be dangerous due to scavenging birds hitting airplanes.

\section{Distance from Railways}

Studies show that a railway line and station must be more than $500 \mathrm{~m}$ away [8], whereas a railway line can be used to transfer the bulk of the waste from generation to disposal site, which would help in reducing environmental, social and transportation costs [8]. Multiple polygons around the railway line within the following distances were prepared: 0-200, 200-500, $500-1000,>1000 \mathrm{~m}$, while a $0-200 \mathrm{~m}$ buffer area was omitted for landfill siting.

\section{Distance from Existing Dumping Sites}

A landfill site must be away from existing dump sites, as a safe distance is necessary in-between them. The spillover from the dumping site due to a natural hazard can affect the workings of a landfill site. The uncontrolled and unprocessed waste of dumping sites can also damage or contaminate the area surrounding a landfill site. In this study, buffer zones of $0-1000,1000-2500,2500-5000$ and $>5000 \mathrm{~m}$ were created, weights were assigned to them according to their suitability, and a $0-1000 \mathrm{~m}$ buffer area was eliminated.

\section{Distance from Groundwater Depth}

Currently, groundwater pollution has become a major environmental concern. Transportation of contaminants from a landfill site can adversely damage groundwater quality. The flow of pollutants toward the groundwater table depends upon the porosity and permeability of the rocks and soil type of the area. The strata beneath the landfill site drives or impedes the hydraulic activity [38]. 491 groundwater well points are presently functional in Lahore. Kriging was used to interpolate the existing data of tube wells. A landfill exceptionally far from groundwater wells will have the least detrimental impact, and a landfill near groundwater wells will have high negative environmental and public health impacts.

Table 2. Factors and their eigenvector weights for landfill siting.

\begin{tabular}{|c|c|c|c|c|c|c|c|c|c|c|}
\hline & $\begin{array}{l}\text { Existing } \\
\text { Landfill }\end{array}$ & Builtup & Road & $\begin{array}{l}\text { Ground } \\
\text { water }\end{array}$ & $\begin{array}{c}\text { Surface } \\
\text { water }\end{array}$ & Railway & Airport & Geology & $\begin{array}{l}\text { Land } \\
\text { Price }\end{array}$ & $\begin{array}{c}\text { Weight } \\
(\%)\end{array}$ \\
\hline Existing Landfill & 1 & & & & & & & & & 3.93 \\
\hline Builtup & 4 & 1 & & & & & & & & 21.70 \\
\hline Road & 1 & $1 / 7$ & 1 & & & & & & & 4.37 \\
\hline Ground water & 3 & 2 & 4 & 1 & & & & & & 17.44 \\
\hline Surface water & 3 & 1 & 3 & 1 & 1 & & & & & 15.15 \\
\hline Railway & 1 & $1 / 7$ & 1 & $1 / 4$ & $1 / 4$ & 1 & & & & 3.68 \\
\hline Airport & 3 & $1 / 7$ & 1 & $1 / 2$ & $1 / 2$ & 1 & 1 & & & 5.58 \\
\hline Geology & 4 & $1 / 2$ & 4 & 1 & $1 / 3$ & 4 & 2 & 1 & & 11.71 \\
\hline Land Price & 4 & $1 / 2$ & 1 & $1 / 2$ & 2 & 7 & 4 & 2 & 1 & 16.43 \\
\hline
\end{tabular}

Consistency Ratio $=0.6<0.1=$ Acceptable 


\section{Economic Factor}

Land values can play a vital role in the landfill site selection process. In Lahore, land values are higher for the central location instead of the locations present at the periphery. A land price scenario was taken from the Lahore Development Authority (LDA). On that basis, buffer zones were constructed around the restricted areas (high land values) and their surroundings.

\section{Potential Landfill Sites}

\section{Assigning Criteria Weights}

AHP is computed for the 9 criteria selected for landfill site selection in this study, which are shown in Table 2.

\section{Landfill Suitability Analysis Results}

The factors (geology, hydrological conditions, groundwater table, proximity from roads, settlements, airport, existing dumping sites and land price) are not equally important. Table 2 shows that factors like surface water, groundwater and geology are more important than the other factors, as it is more important to protect the groundwater table than to maintain distance from roads. In the fluvial plains, geology coupled with hydrology are the most sensitive factors. Even if everything else is fine, these two factors can totally and absolutely jeopardize the possibility of siting a landfill. The weighted linear combination result showed four classes of suitability levels based on specific threshold values:

i. Unsuitable. ii. Less suitable.

iii. Suitable.

iv. Highly suitable

The red color on the map indicates that these areas are not socially, environmentally and economically acceptable or feasible for any landfill siting, whereas the area represented by green color is highly suitable for landfill siting. Moreover, some of the areas indicated with yellowish color are moderately suitable (Fig. 3). The result shows that $10,158.75$ ha $(6.26 \%)$ of the total area is highly suitable, whereas 3494.32 ha $(2.15 \%)$ is extremely unsuitable. Landfill sites with total areas of less than 50 ha were excluded, because smaller sites are not economically acceptable [24]. To make the selection more precise, the three most significant criteria were used for the evaluation and identification of the best potential landfill site. These criteria are size of landfill, distance from settlement and distance from the city center. The size of a landfill is an important factor that must be considered, as the size of land determines the number of years for which the landfill can be utilized as a waste disposal site. Land that can serve for 10 years or more is considered an acceptible site for a landfill, as it can minimize the cost of site choice and limit the construction costs. Furthermore, another major criterion for the evaluation of the best landfill site is its distance from the city center, because a landfill site far away from the city center can increase transportation costs, making the project economically unfeasible. Moreover, a landfill site should not be located near to any settlements. Landfill sites closer to settlements can impose harmful effects on the populations living nearby. On the bases of these criteria, seven candidate landfill sites were finalized for further comparison.

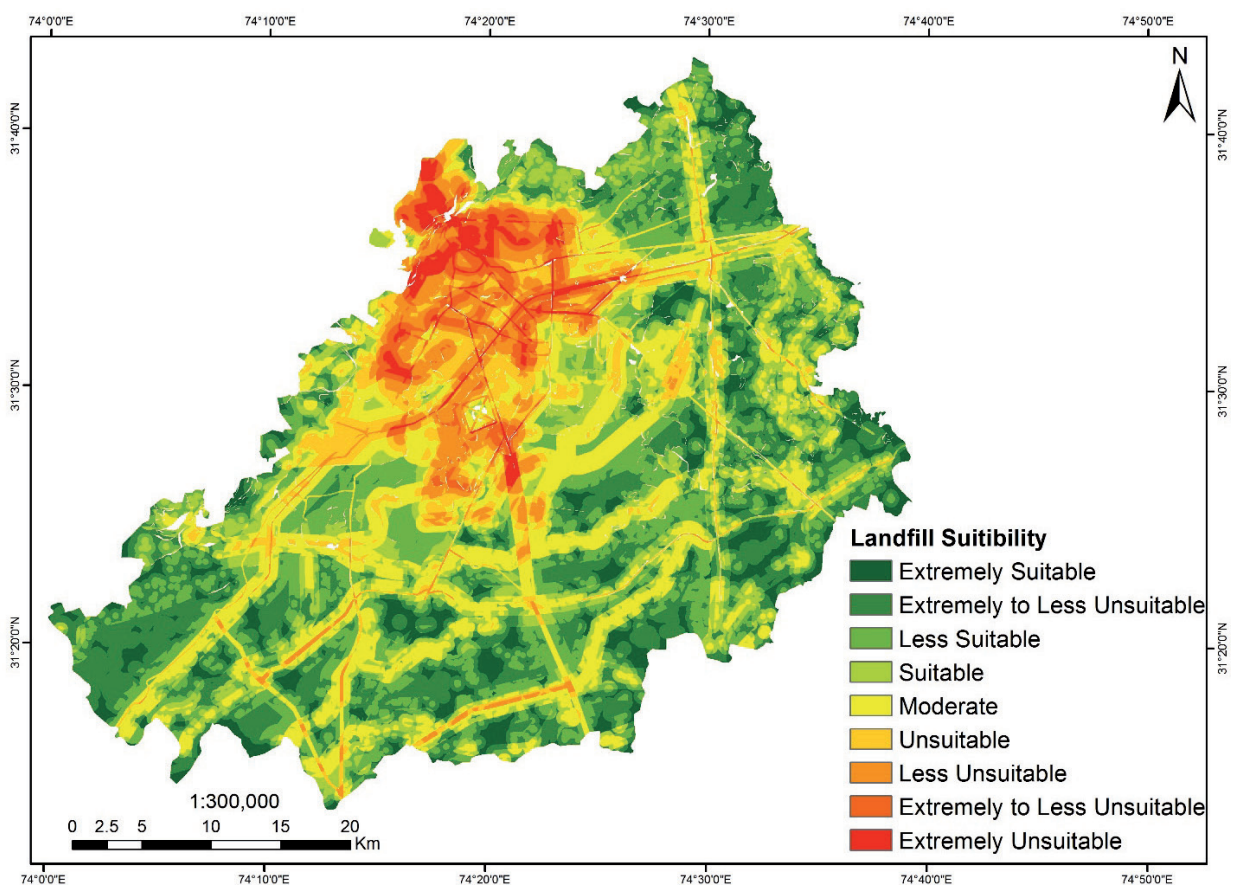

Fig. 3. Landfill suitability map. 
Table 3. Candidate landfill sites with respect to evaluating criteria values.

\begin{tabular}{|c|c|c|c|}
\hline $\begin{array}{c}\text { List of landfill } \\
\text { sites }\end{array}$ & Area (ha) & $\begin{array}{c}\text { Distance from } \\
\text { Center(km) }\end{array}$ & $\begin{array}{c}\text { Distance from } \\
\text { nearby } \\
\text { settlement }(\mathrm{km})\end{array}$ \\
\hline Landfill-1 & 67.390 & 20.00 & 1.36 \\
\hline Landfill-2 & 342.438 & 25.60 & 1.31 \\
\hline Landfill-3 & 63.778 & 17.70 & 0.98 \\
\hline Landfill-4 & 154.659 & 21.90 & 1.23 \\
\hline Landfill-5 & 60.478 & 11.10 & 1.24 \\
\hline Landfill-6 & 181.831 & 19.30 & 1.41 \\
\hline Landfill-7 & 136.805 & 19.60 & 1.02 \\
\hline
\end{tabular}

As shown in Table 3, criteria for suitable landfill site evaluation conflict with one another. For instance, distance from settlement and city center conflict with each other and with landfill size.

MCE addresses such issues in order to select the most appropriate landfill site by considering all three criteria simultaneously for all landfill sites. Finally, these ranks were pooled in a single rank using a linear combination of weight derived from AHP (Table 3) of the three criteria and their ranks. The calculation is the same as follows for Table 2 .

Comparison of the calculated weight for each candidate landfill site with each of the criteria is given below in Tables 5-7 respectively.

Table 4. Pair-wise comparison matrix.

\begin{tabular}{|c|c|c|c|c|c|}
\hline & $\begin{array}{c}\text { Size of } \\
\text { landfill }\end{array}$ & $\begin{array}{c}\text { Distance from } \\
\text { center }\end{array}$ & $\begin{array}{c}\text { Distance from nearby } \\
\text { settlement }\end{array}$ & Weight & Weight (\%) \\
\hline Size of landfill & 1 & & & 0.1692 & 16.92 \\
\hline Distance from center & 3 & 1 & 1 & 0.4434 & 44.34 \\
\hline Distance from nearby settlement & 2 & 1 & 0.3873 & 38.74 \\
\hline
\end{tabular}

$\mathrm{CR}=0.015<<0.1$

Table 5. Weightage w.r.t area.

\begin{tabular}{|c|c|c|c|c|c|c|c|c|c|}
\hline & LF-1 & LF-2 & LF-3 & LF-4 & LF-5 & LF-6 & LF-7 & Weight & Weight (\%) \\
\hline LF-1 & 1 & & & & & & & 0.0826 & 8.26 \\
\hline LF-2 & 6 & 1 & & & & & & 0.3703 & 37.03 \\
\hline LF-3 & $1 / 2$ & $1 / 6$ & 1 & & & & & 0.0861 & 8.61 \\
\hline LF-4 & 2 & $1 / 3$ & 3 & 1 & & & & 0.1637 & 16.37 \\
\hline LF-5 & $1 / 3$ & $1 / 7$ & $1 / 2$ & $1 / 5$ & 1 & & & 0.0316 & 3.16 \\
\hline LF-6 & 3 & $1 / 2$ & 2 & 1 & 6 & 1 & & 0.1781 & 17.81 \\
\hline LF-7 & 1 & $1 / 4$ & 1 & $1 / 2$ & 4 & $1 / 2$ & 1 & 0.0876 & 8.76 \\
\hline
\end{tabular}

$\mathrm{CI}=0.116, \mathrm{CR}=0.088<<0.1$

Table 6. Weightage w.r.t distance from city center.

\begin{tabular}{|c|c|c|c|c|c|c|c|c|c|}
\hline & LF-1 & LF-2 & LF-3 & LF-4 & LF-5 & LF-6 & LF-7 & Weight & Weight (\%) \\
\hline LF-1 & 1 & & & & & & & 0.1185 & 11.85 \\
\hline LF-2 & $1 / 5$ & 1 & & & & & & 0.0378 & 3.78 \\
\hline LF-3 & 3 & 5 & 1 & & & & & 0.1622 & 16.22 \\
\hline LF-4 & $1 / 2$ & 2 & $1 / 4$ & 1 & & & & 0.0614 & 6.14 \\
\hline LF-5 & 4 & 6 & 2 & 5 & 1 & & & 0.3642 & 36.42 \\
\hline LF-6 & 2 & 4 & $1 / 2$ & 3 & $1 / 3$ & 1 & & 0.1343 & 13.43 \\
\hline LF-7 & $1 / 2$ & 3 & $1 / 2$ & 2 & $1 / 3$ & 2 & 1 & 0.1216 & 12.16 \\
\hline
\end{tabular}

$\mathrm{CI}=0.023, \mathrm{CR}=0.018<<0.1$ 
Table 7. Weightage w.r.t distance from nearby settlement.

\begin{tabular}{|c|c|c|c|c|c|c|c|c|c|}
\hline & LF-1 & LF-2 & LF-3 & LF-4 & LF-5 & LF-6 & LF-7 & Weight & Weight (\%) \\
\hline LF-1 & 1 & & & & & & & 0.2398 & 23.98 \\
\hline LF-2 & $1 / 2$ & 1 & & & & & & 0.1638 & 16.38 \\
\hline LF-3 & $1 / 6$ & $1 / 5$ & 1 & & & & & 0.0404 & 4.04 \\
\hline LF-4 & $1 / 4$ & $1 / 3$ & 3 & 1 & & & & 0.0674 & 6.74 \\
\hline LF-5 & $1 / 3$ & $1 / 2$ & 4 & 2 & 1 & & & 0.1034 & 10.34 \\
\hline LF-6 & 2 & 3 & 6 & 5 & 4 & 1 & & 0.3420 & 34.20 \\
\hline LF-7 & $1 / 5$ & $1 / 5$ & 2 & $1 / 2$ & $1 / 3$ & $1 / 6$ & 1 & 0.0432 & 4.32 \\
\hline
\end{tabular}

$\mathrm{CI}=0.086, \mathrm{CR}=0.065<<0.1$

Table 8. Ranking of the candidate landfill sites.

\begin{tabular}{|c|c|c|c|c|c|c|c|c|c|c|c|c|}
\hline $\begin{array}{l}\text { List of } \\
\text { landfill }\end{array}$ & \multicolumn{3}{|c|}{ Area capacity } & \multicolumn{3}{|c|}{ Distance from center } & \multicolumn{3}{|c|}{$\begin{array}{c}\text { Distance from nearby } \\
\text { settlement }\end{array}$} & $\begin{array}{l}\text { Weight of } \\
\text { candidate }\end{array}$ & $\begin{array}{c}\text { Weight of } \\
\text { candidate landfill }\end{array}$ & Rank \\
\hline Landfill-1 & \multirow{7}{*}{0.1692} & 0.0826 & 0.0140 & \multirow{7}{*}{0.4434} & 0.1185 & 0.0525 & \multirow{7}{*}{0.3874} & 0.2398 & 0.0929 & 0.1594 & 15.94 & 3 \\
\hline Landfill-2 & & 0.3703 & 0.0627 & & 0.0378 & 0.0167 & & 0.1638 & 0.0635 & 0.1428 & 14.28 & 4 \\
\hline Landfill-3 & & 0.0861 & 0.0146 & & 0.1622 & 0.0719 & & 0.0404 & 0.0157 & 0.1021 & 10.21 & 5 \\
\hline Landfill-4 & & 0.1637 & 0.0277 & & 0.0614 & 0.0272 & & 0.0674 & 0.0261 & 0.0810 & 8.10 & 7 \\
\hline Landfill-5 & & 0.0316 & 0.0053 & & 0.3642 & 0.1615 & & 0.1034 & 0.0401 & 0.2069 & 20.69 & 2 \\
\hline Landfill-6 & & 0.1781 & 0.0301 & & 0.1343 & 0.0595 & & 0.3420 & 0.1325 & 0.2221 & 22.21 & 1 \\
\hline Landfill-7 & & 0.0167 & 0.0148 & & 0.1216 & 0.0539 & & 0.0432 & 0.0167 & 0.0855 & 8.55 & 6 \\
\hline
\end{tabular}

The above results of Tables 5-7 show that landfill sites 2, 5 and 6 are best with respect to area, distance from city center and nearby settlements respectively.
These sites are present in the southern part of the city. In order to tackle the conflicting criteria for selecting the most appropriate landfill site, all the assessed

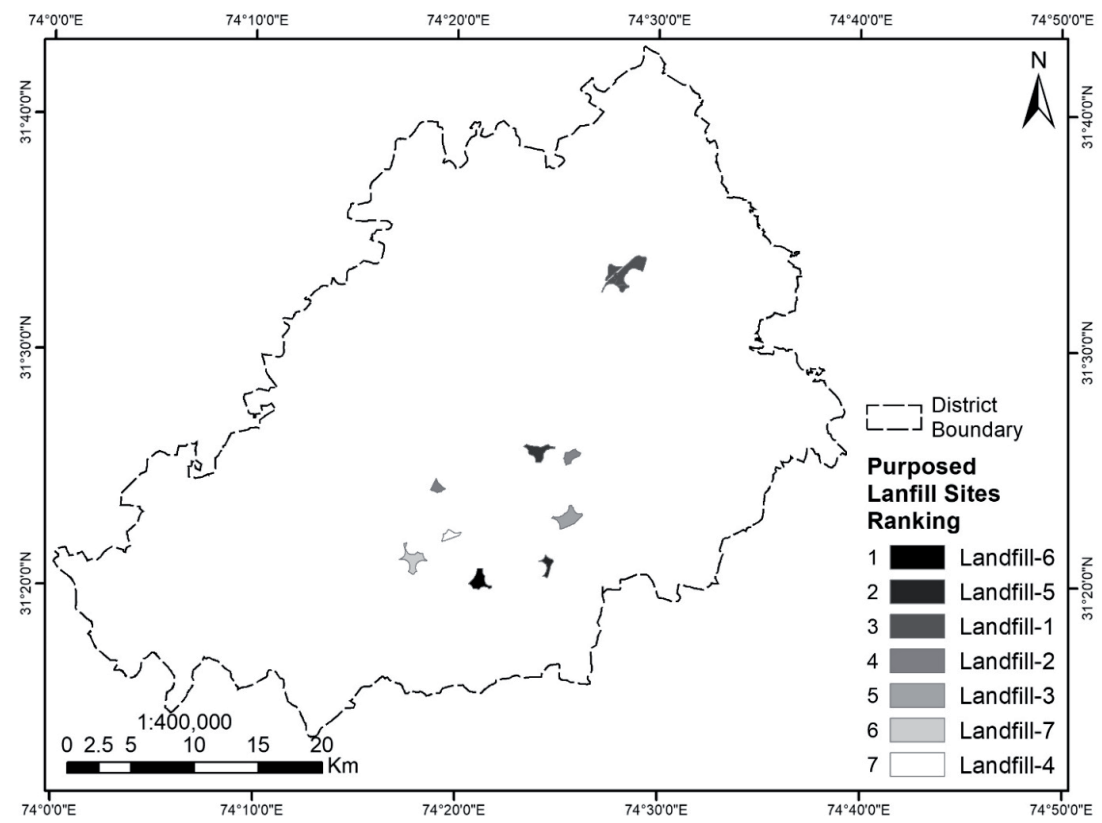

Fig. 4. Suitable landfill sites map. 
criteria were considered together using MCE. Therefore, cumulative weights were assigned to select the landfill site, depending upon area and distance from center and settlement (Table 8).

Table 8 demonstrates that landfill site 6 , with a weight $0.22(22.21 \%)$ is the most suitable when compared with the rest of the landfill sites (Fig. 4).

This shows that this site fulfills the criteria set with respect to the rest of the landfill locales. Landfill 4, with a weight of $0.08(8.10 \%)$, is the least preferable landfill site. In addition, landfill sites 5 and 1, with weights $0.21(20.69 \%)$ and $0.16(15.94 \%)$ respectively, ranked as second and third preferable landfill sites due to their weights. Moreover, landfill sites 2, 3 and 7, with weights $0.14(14.28 \%), 0.10(10.21 \%)$ and $0.09(8.55 \%)$, are ranked fourth, fifth and sixth respectively.

Ideally, a landfill is suitable for non-hazardous municipal waste. It should not contain household waste like batteries, paints and motor oil, etc. Some of the non-hazardous commercial and industrial waste can also become part of a landfill. In order to lessen the environmental burden, on-site segregation of waste is recommended. It may also promote the recycling of waste. Organic materials continue to be the largest component of municipal solid waste (MSW). Yard trimmings and food scraps account for $67.02 \%$ and paper and paperboard account for another 5.04\%. Plastics comprise $18.49 \%$, while metals make up $0.49 \%$. Textiles account for $1 \%$ and glass accounts for $2.19 \%$. Other miscellaneous wastes make up approximately $5.77 \%$ of the MSW generated in Lahore [39].

At present there is only one so-called sanitary landfill site in Lahore. This site was selected by experts for or on behalf of LWMC. This site is present on the northern side of the city. The location of this landfill site is extremely unsuitable with respect to the geological conditions, surface water bodies and groundwater resources. The geological conditions of this location clearly identify the presence of porous sediments beneath the surface, which is not suitable for landfill site construction. It is situated in the channel belt sand of an abandoned Ravi channel with either negative or just below the surface water table. So the contaminated runoff from the landfill has an adverse impact on the surface water bodies as well as on the groundwater resources. Almost $80 \%$ of the recharge for the Lahore city aquifer is from the Ravi. Lahore uses groundwater for its various needs, including domestic water supply. Most of the Lahore population uses this water for drinking. The current location of this existing landfill site depicts that this site is not economically suitable due to the high transportation cost. It also creates a nuisance while transferring waste from the southern to the northern side of the city. On the other hand, the core objective of this study was to identify the best location for a landfill site in Lahore that not only protects the environment but also lessens the economic costs associated with maintenance and use of the landfill. Therefore, the site must be a suitable distance from the human population to prevent health issues. The areas suggested in this study are at a reasonable distance from groundwater and surface water bodies. The geology of this area helps prevent leachate penetration. Moreover, these areas are at an appropriate distance from city center and from major road networks so they help in reducing transportation cost. Whereas the ecosystem of landfill sites is an important parameter for decision making, a major land area for the proposed landfill site 6 is barren, and only small grasses are present. Its distance from water bodies and residential areas also strengthen its choice. Groundwater is at a depth of $60 \mathrm{~m}$ and the top layer of the fluvial package is thick clay ( $>20 \mathrm{~m}$ thick). The market price of this land is low, and this site falls in the barren area that can be used for compositing and other important landfilling procedures.

\section{Conclusions}

In Lahore, most solid waste disposal is done through open dumping. Major waste generation sources are domestic, industrial, agricultural and hospital. Due to lack of segregation, hazardous and non-hazardous wastes are mixed, and this waste becomes part of a dumping site without segregation. Furthermore, one of the major dumping sites as well as the newly constructed landfill sites is very close to the main surface water body, i.e., the River Ravi. The landfill site is constructed on the main river bed with poor geological conditions and will eventually pollute the water through its leachate. The map shows that the dumping site and landfill site are also very close to settlements, which is neither environmentally nor socially acceptable.

This study has considered nine parameters: geology, proximity from built-up areas, roads, airports, railways, existing dumping sites, groundwater wells, surface water resources and land price. Incorporating AHP with GIS for a spatial decision-making process is complicated as it deals with the huge and conflicting criteria in landfill site selection. Landfill suitability maps were prepared in GIS. The result shows that $10,158.75$ ha $(6.26 \%)$ of the total area is highly suitable, whereas 3494.32 ha $(2.15 \%)$ is extremely unsuitable. After applying a buffer of $15 \mathrm{~km}, 7$ candidate landfill sites were chosen. These selected landfill locations were contrasted with each other on the basis of their land size, distance from close settlements and distance from the city center. In order to identify the most suitable landfill site location among these, an AHP pair-wise comparison was applied.

Weights were derived for each criterion and for all the selected landfill sites through AHP. As a result of this analysis, landfill site 6 scored the highest weight of $22.21 \%$. On the other hand, landfill site 4 scored the lowest weight, i.e., $8.10 \%$. Therefore, landfill site 6 , which is in the southern side of Lahore, is considered the most appropriate site among the 7 proposed landfill sites. This site has the least environmental and social 
impacts, as it is at a reasonable distance from settlements and is at the same time comparatively closer to the city center. The rest of the sites were ranked according to their scores. All of these sites have less environmental and social impacts.

\section{Conflict of Interest}

The authors declare no conflict of interest.

\section{References}

1. JADOON A., BATOOL S.A., CHAUDHRY M.N. Assessment of factors affecting household solid waste generation and its composition in Gulberg Town, Lahore, Pakistan. J.Mater. Cycles. Waste. 16 (1), 73, 2014.

2. ALI M., ASHRAF U., CHAUDHRY N., GENG Y. Unsafe waste management practices and hepatitis $\mathrm{C}$ among hospital sanitary staff in Pakistan. J. Hosp. Infect. 96 (1), 95, 2017.

3. ZUBERI M.J.S., ALI S.F. Greenhouse effect reduction by recovering energy from waste landfills in Pakistan. Renew. Sust. Energ. Rev. 44, 117, 2015.

4. ALI M., WANG W., CHAUDHRY N. Application of life cycle assessment for hospital solid waste management: A case study. J. Air Waste Manage. Assoc. 66 (10), 1012, 2016.

5. NAS B., CAY T., ISCAN F., BERKTAY A. Selection of MSW landfill site for Konya, Turkey using GIS and multicriteria evaluation. Environ. Monit. Assess. 160 (1), 491, 2010.

6. WEITZ K., BARLAZ M., RANJITHAN R., BRILL D., THORNELOE S., HAM R. Life cycle management of municipal solid waste. Int. J. LCA. 4 (4), 195, 1999.

7. WANG G., QIN L., LI G., CHEN L. Landfill site selection using spatial information technologies and AHP: a case study in Beijing, China. J. Environ. Manage. 90 (8), 2414, 2009.

8. ALANBARI M., AL-ANSARI N., JASIM H., KNUTSSON S. Modeling landfill suitability based on GIS and multicriteria decision analysis: case study in Al-Mahaweel Qadaa. Nat. Sci. 6 (11), 828, 2014.

9. MOTLAGH Z.K., SAYADI M.H. Siting MSW landfills using MCE methodology in GIS environment (Case study: Birjand plain, Iran). Waste Manage. 46, 322, 2015.

10. AMAN A., HOPKINSON G. The Changing Structure of Distribution Channels in Pakistan. Int. J. Ret. Distrib. Manag. 38 (5), 341, 2010.

11. KAMRAN A., CHAUDHRY M.N., BATOOL S.A. Role of the Informal Sector in Recycling Waste in Eastern Lahore. Pol. J. Environ. Stud. 24 (2), 2015.

12. SADEF Y., NIZAMI A.S., BATOOL S.A., CHAUDARY M.N., OUDA O.K.M., ASAM Z.Z., DEMIRBAS A. Waste-to-energy and recycling value for developing integrated solid waste management plan in Lahore. Energy Sources, Part B. 11 (7), 569, 2016.

13. SAJJAD S.H., BATOOL R., QADRI S.T., SHIRAZI S.A., SHAKRULLAH K. The long-term variability in minimum and maximum temperature trends and heat island of Lahore city, Pakistan. Sci. Int. 27 (2), 1321, 2015.

14. MUHAMMAD A.M., ZHONGHUA T. Municipal solid waste and its relation with groundwater contamination in
Lahore, Pakistan. Res. J. Appl. Sci. Eng. Technol. 7 (8), 1551, 2014.

15. GBANIE S.P., TENGBE P.B., MOMOH J.S., MEDO J., KABBA V.T.S. Modelling landfill location using geographic information systems (GIS) and multi-criteria decision analysis (MCDA): case study Bo, Southern Sierra Leone. Appl. Geogr. 36, 3, 2013.

16. DE FEO G., DE GISI S. Using MCDA and GIS for hazardous waste landfill siting considering land scarcity for waste disposal. Waste Manage. 34 (11), 2225, 2014.

17. YILMAZ B. Application of GIS-Based Fuzzy Logic and Analytical Hierarchy Process (AHP) to Snow Avalanche Susceptibility Mapping, North San Juan, Colorado, 2016.

18. ADEFRIS A. Evaluation of solid waste landfill potential site using GIS based multi criteria evaluation method: a case study of Addis Ababa. Addis Ababa University, Ethiopia, 5, 2015.

19. CHURCH R. L. Geographical information systems and location science. Comput. Oper. Res. 29 (6), 541, 2002.

20. MALCZEWSKI J. GIS-based land-use suitability analysis: a critical overview. Prog. Plann. 62 (1), 3, 2004.

21. HIGGS G. Integrating multi-criteria techniques with geographical information systems in waste facility location to enhance public participation. Waste Manage. Res. 24 (2), 105, 2006.

22. GRECO S., FIGUEIRA J., EHRGOTT M. Multiple criteria decision analysis. Springer's International Series, 2016.

23. MOEINADDINI M., KHORASANI N., DANEHKAR A., DARVISHSEFAT A. A. Siting MSW landfill using weighted linear combination and analytical hierarchy process (AHP) methodology in GIS environment (case study: Karaj). Waste Manage. 30 (5), 912, 2010.

24. KHAN D., SAMADDER S.R. A simplified multi-criteria evaluation model for landfill site ranking and selection based on AHP and GIS. J. Environ. Eng. Landsc. 23 (4), 267, 2015.

25. HASAN M.R., TETSUO K., ISLAM S.A. Landfill demand and allocation for municipal solid waste disposal in Dhaka city - an assessment in a GIS environment. J. Civ. Eng. 37 (2), 133, 2009.

26. SAATY T.L. A scaling method for priorities in hierarchical structures. J. Math. Psychol. 15 (3), 234, 1997.

27. MANUAL M.S.W. Manual on municipal solid waste management. Ministry of urban development, Government of India, India, 2000.

28. FAROOQI A., MASUDA H., FIRDOUS N. Toxic fluoride and arsenic contaminated groundwater in the Lahore and Kasur districts, Punjab, Pakistan and possible contaminant sources. Environ. Pollut. 145 (3), 839, 2007.

29. ŞENER B., SÜZEN M.L., DOYURAN V. Landfill site selection by using geographic information systems. Environ. Geol. 49 (3), 376, 2006.

30. KHIZAR H. Geotechnical Zonation and Their Relation to Geology of Pakistan (Ph.D. Thesis). Lahore: College of Earth and Environmental Sciences, University of the Punjab, 2003.

31. ASHRAF M., CHAUDHRY M.N., HUSSAIN S.S. General geology and economic significance of the Lahore granite and rocks of the southern ophiolite belt in the Allai-Kohistan area. Geol. Bull. Univ. Peshawar,. 13, 207, 1980.

32. CHANDIO I.A., MATORI A.N.B., WANYUSOF K.B., TALPUR M.A.H., BALOGUN A.-L., LAWAL D.U. GIS-based analytic hierarchy process as a multicriteria decision analysis instrument: a review. Arab. J. Geosci. 6 (8), 3059, 2012. 
33. ISSA S., SHEHHI B. A gis-based multi-criteria evaluation system for selection of landfill sites: a case study from Abu Dhabi, United Arab Emirates. International Archives of the Photogrammetry, Remot. Sens. Spat. Informat. Sci. 39, 2012.

34. PAUL S. Location allocation for urban waste disposal site using multi-criteria analysis: A study on Nabadwip Municipality, West Bengal, India. Int. J. Geomat. Geosci. 3 (1), 74, 2012.

35. ALLEN A., BRITO G., CAETANO P., COSTA C., CUMMINS V., DONNELLY J., VENDAS D. The Development of a GIS Model for the Location of Landfill Sites in Ireland and Portugal. 2011.
36. BAGCHI A. Design, construction, and monitoring of landfills. 1994.

37. CHALKIAS C., STOURNARAS G. GIS application for the selection of sanitary waste disposal landfills and quarry sites in major Sparti area, Greece. Engineering Geology and the Environment, AA Balkema, Rotterdam, 267, 1997.

38. ABEBE T., MANETTI P. Geological map of the northern main Ethiopian Rift: Geological Society of America. 2015.

39. BATOOL S. A., CHAUDHRY M. N. Municipal solid waste management in Lahore city district, Pakistan. Waste Manage. 29 (6), 1971, 2009. 
